\title{
Order out of chaos
}

\author{
Alden H. Harken, MD, FACS
}

From the Department of Surgery, University of California, San Francisco-East Bay, Oakland, Calif. Disclosures: Author has nothing to disclose with regard to commercial support.

Received for publication Jan 18, 2017; accepted for publication Jan 31, 2017; available ahead of print March 6, 2017.

Address for reprints: Alden H. Harken, MD, FACS, Department of Surgery, University of California, San Francisco-East Bay, 1411 E 31st St (QIC 22134), Oakland, CA 94602 (E-mail: alden.harken@ucsfmedetr.org). J Thorac Cardiovasc Surg 2017;153:1085-6

$0022-5223 / \$ 36.00$

Copyright (C) 2017 by The American Association for Thoracic Surgery

http://dx.doi.org/10.1016/j.jtcvs.2017.01.042

We all like to think that we make progress-incremental improvements in standard diagnoses and therapy. It is rare, however, for one of us to achieve the orbital leap of identifying a therapeutic pattern within apparent randomness. In the mid 1980s, Jim Cox and Jack Boineau began exploring atrial activation patterns with 156 epicardial electrodes, and they recognized patterns-even within atrial fibrillation. ${ }^{1}$ In sinus rhythm, with age, the sinoatrial node appeared to sag down into the lateral right atrium. Maybe all the anatomy books were wrong. Extranodal atrial escape impulses originated from as many as 4 widely distributed atrial pacemaker sites. ${ }^{2}$ Perhaps the apparent causes of atrial fibrillation could also be mapped. ${ }^{3,4}$ If atrial fibrillation revealed mappable patterns, this common arrhythmia was not a large group of isolated, angry cardiomyocytes firing independently and unpredictably (automatic arrhythmia).

A mappable circuit rhythm had to be reentrant. For a reentrant rhythm to be sustained, 3 characteristics are obligatory: (1) areas of slow conduction, (2) rapid refractoriness, and (3) zones of unidirectional block. Conceptually, then, the larger the area of "at-risk" atrial muscle, the longer it should take the reentrant impulse to course the length of the pathway. This delay would permit the origin of the impulse to repolarize before the reentrant impulse returned to stimulate it again.

This hypothesis should confer 2 clinically observable and testable outcomes. (1) Antiarrhythmic drugs that slow impulse conduction velocity should prove to be proarrhythmic (we all now know this to be true). (2) By cutting the atrium into strips too narrow to sustain a reentrant arrhythmia, atrial fibrillation should be surgically curable (thus the Cox-maze procedure).

In an attempt to guarantee success, Jim Cox designed the early Cox-maze procedure to slice the entire right and left atria into narrow ribbons-leaving an errant reentrant impulse with no chance of success. This early procedure resulted in atrial remnants with all the anatomic characteristics of a lawnmower accident. For most of us, pasting the atria back together proved to be a timeconsuming surgical challenge. Continued refinement of

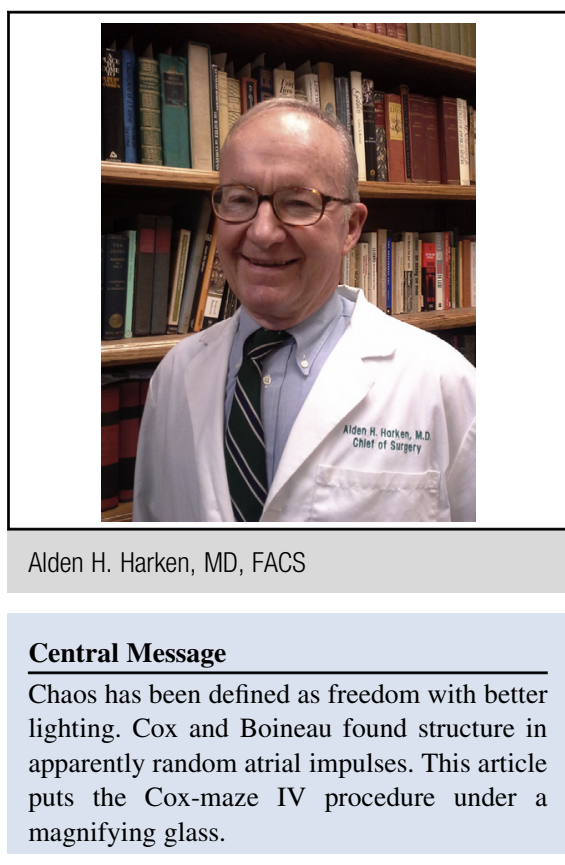

See Article page 1087.

the procedure at Washington University in St Louis with radiofrequency probes has simplified the repair. These ablative reentrant impulse barriers have permitted the Coxmaze procedure to be routinely tacked on to other standard surgical procedures.

The study in this issue of the Journal by Schill and colleagues ${ }^{5}$ presents superb surgical results of 83 patients who, in addition to coronary artery bypass grafting, benefited from a concurrent arrhythmia ablation. At 1 year, $98 \%$ of these patients were free of arrhythmia, and $88 \%$ were no longer receiving any arrhythmia medications. The surgical results of this combined Cox-maze IV and coronary artery bypass grafting procedure are superior to the recent meta-analysis of more than 6000 patients treated with a single catheter ablative procedure.

During the period of this study, the Washington University surgical group performed coronary artery bypass grafting alone on 586 patients with atrial fibrillation..$^{5}$ One wonders why only 135 patients were offered the concurrent, formidably successful arrhythmia therapy. I guess they are still learning. That's good.

\section{References}

1. Boineau JP, Canavan TE, Schuessler RB, Cain ME, Corr PB, Cox JL. Demonstration of a widely distributed atrial pacemaker complex in the human heart. Circulation. 1988;77:1221-37. 
2. Ferguson TB Jr, Schuessler RB, Hand DE, Boineau JP, Cox JL. Lessons learned from computerized mapping of the atrium. Surgery for atrial fibrillation and atrial flutter. J Electrocardiol. 1993;26(Suppl):210-9.

3. Cox JL, Schuessler RB, Boineau JP. The surgical treatment of atrial fibrillation. I. Summary of the current concepts of the mechanisms of atrial flutter and atrial fibrillation. J Thorac Cardiovasc Surg. 1991;101: $402-5$.
4. Cox JL, Canavan TE, Schuessler RB, Cain ME, Lindsay BD, Stone C, et al. The surgical treatment of atrial fibrillation. II. Intraoperative electrophysiologic mapping and description of the electrophysiologic basis of atrial flutter and atrial fibrillation. J Thorac Cardiovasc Surg. 1991;101:406-26.

5. Schill MR, Musharbash FN, Hansalia V, Greenberg JW, Melby SJ, Maniar HS, et al. Late results of the Cox-maze IV procedure in patients undergoing coronary artery bypass grafting. J Thorac Cardiovasc Surg. 2017;153:1087-94. 